Blockchain and Artificial Intelligence 



\section{Blockchain and Artificial Intelligence}

The World Rewired

Edited by

Tom James

DE GRUYTER 
ISBN 978-3-11-066114-9

e-ISBN (PDF) 978-3-11-066445-4

e-ISBN (EPUB) 978-3-11-066134-7

Library of Congress Control Number: 2021941384

Bibliographic information published by the Deutsche Nationalbibliothek

The Deutsche Nationalbibliothek lists this publication in the Deutsche Nationalbibliografie; detailed bibliographic data are available on the internet at http://dnb.dnb.de.

(C) 2021 Walter de Gruyter GmbH, Berlin/Boston

Cover image: Ryzhi/iStock/Getty Images Plus

Typesetting: Integra Software Services Pvt. Ltd.

Printing and binding: $\mathrm{CPI}$ books $\mathrm{GmbH}$, Leck

www.degruyter.com 